\title{
Aqueous root extract of Asparagus cochinchinensis (Lour.) Merr. Has antioxidant activity in D-galactose-induced aging mice
}

\author{
Linghua Lei ${ }^{1,2 \dagger}$, Yanhua Chen ${ }^{2,4 \dagger}$, Lijun $\mathrm{Ou}^{3}$, Yinglong $\mathrm{Xu}^{2^{*}}$ and Xiaoying $\mathrm{Yu}^{2^{*}}$
}

\begin{abstract}
Background: Extracts of plants have been considered as sources of natural antioxidant agents. In this study, we aimed to explore the antioxidant capacity of the aqueous root extract of Asparagus cochinchinensis (Lour.) Merr.

Methods: Using vitamin C (Vc) as a positive control, we analyzed the aqueous root extract of $A$. cochinchinensis free radical scavenging ability in vitro. We also established a mouse aging model using D-galactose and then treated it with aqueous root extract or Vc. The blood cell count and superoxide dismutase (SOD), catalase (CAT), and nitric oxide synthase (NOS) activities as well as malondialdehyde (MDA) and nitric oxide (NO) contents were measured; pathological examination of tissues was performed; and SOD, glutathione peroxidase (GPX), and NOS expression levels in the serum, liver, and brain tissues were investigated.
\end{abstract}

Results: In vitro, compared with the antioxidant Vc, the aqueous root extract showed similar 1,1-Diphenyl-2picrylhydrazyl radical and 3-ethylbenzothiazoline-6-sulfonic-scavenging activities and even significantly increased superoxide anion $(p<0.05)$ and hydroxyl radical $(\mathrm{OH})(p<0.01)$ scavenging activities. The aqueous extract significantly increased the white blood cell count as well as enhanced SOD, CAT, and NOS activities $(p<0.01)$ in aging mice. In addition, the aqueous extract increased the NO content $(p<0.05)$ and reduced the MDA content $(p<0.05)$.

Conclusions: The aqueous root extract of A. cochinchinensis showed as strong antioxidant ability as Vc and might prevent aging by reducing radicals.

Keywords: Asparagus cochinchinensis (Lour.) Merr., Antioxidant, Aging, Enzyme activity, Root

\section{Background}

Aging, which refers to a multidimensional process of physical and psychological changes, is closely related to most human diseases [1]. Aging is associated with reduced antioxidant enzyme, such as superoxide dismutase (SOD), activities, thereby attenuating the removal of oxygen radicals [2]. Currently, exogenous radical scavengers, such as butyl hydroxy toluene, butylated hydroxylanisole, and tert-butylhydroquinone, have been successfully used for resisting disease development [3]. However, the toxicity of artificial antioxidants can lead to

\footnotetext{
*Correspondence: xuyinglongxyl@163.com; xiaoyingyuyuu@yeah.net ${ }^{\dagger}$ Equal contributors

${ }^{2}$ College of Horticulture and Landscape, Hunan Agriculture University, Changsha, Hunan 410128, China

Full list of author information is available at the end of the article
}

risks of DNA damage and malignancy [4]. Thus, the safety of artificial antioxidants remains a subject of debate [5].

Natural antioxidants have attracted attention as replacements for artificial antioxidants, [6]. Okra leaf [7] and Rubus alceifolius Poir [8], which are traditional Chinese medicines, are deemed to be potential resources of natural antioxidants. Asparagus cochinchinensis (Lour.) Merr. (A. cochinchinensis), one of the medicinally important plants, has antibacterial, anti-inflammatory, anticancer, and antioxidant effects [9-12]. A methanol extract from A. cochinchinensis has a neuroprotective effect in cerebral infarction model animals [13]. Our recent study also demonstrated the antioxidant ability of shoot extract of $A$. cochinchinensis in mice with $\mathrm{D}$-galactose-induced aging [14]. However, antioxidant effects of the tuberous root of A. cochinchinensis remain unclear. 
A previous study revealed that an aging model can be induced using D-galactose [15]. In this study, Dgalactose-induced aging mouse model was established, and then the aging mice were treated with aqueous root extract or Vc. The blood cell count and superoxide dismutase (SOD), catalase (CAT), and nitric oxide synthase (NOS) activities as well as malondialdehyde (MDA) and nitric oxide (NO) contents were measured; pathological examination of tissues was performed; and SOD, glutathione peroxidase (GPX), and NOS expression levels in serum, liver, and brain tissues was investigated. In addition, we investigated the effect of the aqueous root extract of $A$. cochinchinensis on radical scavenging ability in vitro. We also aimed to explore the antioxidant mechanism and further application of the aqueous root extract of $A$. cochinchinensis.

\section{Methods}

\section{Pharmaceutical preparation}

The aqueous root extract was prepared as described previously [16]. A. cochinchinensis specimens were collected from Lewang Town, Wangmo County, Buyi and Miao Nationalities Autonomous Prefecture, Guizhou Province, and identified by Professor Wu Xian at Hunan Huaihua College. This material (voucher specimen number: HJH20150930013) was deposited in the Plant Herbarium, Institute of Biology, Guizhou Academy of Sciences. The roots of $A$. cochinchinensis were dried with hot air. After grinding, powdered roots $(20 \mathrm{~g})$ were dissolved in water $(160 \mathrm{~mL})$, and then boiled and extracted three times. The three extracts were combined, filtered, and concentrated using a rotating evaporator to obtain the aqueous extracts of $A$. cochinchinensis, in accordance with Chinese pharmacopoeia [17]. Theaqueous extracts were dissolved in distilled water to a stocking solution of $0.7 \mathrm{~g} / \mathrm{mL}$ and frozen until use.

\section{Measurement of radical scavenging ability in vitro} 1,1-Diphenyl-2-picrylhydrazyl radical (DPPH) has been widely used for antioxidant assays. DPPH.and 3ethylbenzothiazoline-6-sulfonic $\left(\mathrm{ABTS}^{+}\right)$scavenging activities was measured in accordance with the procedure described in our previous report [14]. In brief, $2 \mathrm{~mL}$ of $0.7 \mathrm{~g} / \mathrm{mL}$ root extract solution was reacted with $2 \mathrm{~mL}$ of $1.25 \times 10^{-4} \mathrm{~mol} / \mathrm{L} \mathrm{DPPH}$ or $30 \mu \mathrm{L}$ of $0.7 \mathrm{~g} / \mathrm{mL}$ root extract solution was reacted with $3 \mathrm{~mL}$ of $7 \mathrm{mmol} / \mathrm{L}$ $\mathrm{ABTS}^{+}$at room temperature in the dark, after which the absorbance was detected at 517 or $734 \mathrm{~nm}$, respectively. Negative and positive controls were ethanol (solvent) and vitamin $\mathrm{C}(\mathrm{Vc})$, respectively. Furthermore, the superoxide anion and hydroxyl radical $(\mathrm{OH})$ levels were measured using commercial kits (Jiangcheng Bioengineering Institute, Nanjing, China). The absorption value was detected using a microplate reader (Thermo).

\section{Animal models and drug treatment}

Approval was obtained from the Animal Ethics Committee of the Animal Laboratory Center of Xiangya Medical School of Central South University prior to using the animals for the following experiments. In total, 80 healthy male KunMing (KM) mice, which weighed $20 \pm 2 \mathrm{~g}$ and were aged 2 months old, were provided by the Xiangya Medical School of Central South University. Mice were randomly and equally assigned to four groups: negative control, aging model, Vc positive control, and extract treatment. Mice in the negative control group were subcutaneously injected with saline $(100 \mathrm{mg} / \mathrm{kg})$ daily. In the aging model group, aging was induced by $\mathrm{D}$-galactose, in accordance with a previously described method [18]. Mice in the aging model, $\mathrm{Vc}$ positive control, and extract treatment groups received a subcutaneous injection of $500 \mathrm{mg} / \mathrm{kg} \mathrm{D-}$ galactose daily; meanwhile, mice in Vc positive control or extract treatment groups were treated with Vc or aqueous root extract $(200 \mathrm{mg} / \mathrm{kg})$ daily by intragastric administration for 30 consecutive days.

\section{Preparation of blood and pathological tissue sample}

After the final drug administration for $24 \mathrm{~h}, 20 \mu \mathrm{L}$ blood samples were taken by eyeball extirpation and then centrifuged at $3000 \mathrm{r} / \mathrm{min}$ for $10 \mathrm{~min}$. The supernatant was used for the following experiments.

The mice were killed and then their brains, hearts, kidneys, and livers were isolated. Tissues were pre-fixed in Bouin's solution for $24 \mathrm{~h}$, followed by gradient ethanol dehydration, paraffin embedding, slicing $(5-7 \mu \mathrm{m})$, and regular HE staining. Finally, a microscope (Motic Group Co., Ltd., Xiamen, China) was used to observe these sections.

\section{Measurements of the NOS, SOD, and CAT activities and NO and MDA contents}

Tissues (including livers, kidneys, hearts, and brains; 0.3$0.6 \mathrm{~g}$ ) were ground. After centrifugation at $1000 \mathrm{r} / \mathrm{min}$ for 5 min, NOS, SOD, and CAT activities as well as NO and MDA contents in the supernatants were measured using commercial kits (Jiangcheng Bioengineering Institute).

\section{Semi-quantitative reverse-transcription polymerase chain reaction (RT-PCR)}

Total mRNA of the serum was extracted using an RNA extraction kit (Ambiogen Life Science Technology Ltd.). Then, cDNA was synthesized using a first-strand cDNA synthesis kit (Tiangen Biotech Co., Ltd., Beijing, China). Primers used in the present study are shown in Table 1. PCR reaction was conducted in a $50 \mathrm{~mm}^{3}$ system containing $5.0 \mathrm{~mm}^{3}$ of $10 \times$ PCR buffer, 10 pmol forward and reverse primers, $0.3 \mathrm{~mm}^{3}$ of $10 \mathrm{mM}$ dNTPs, $2 \mathrm{U}$ Taq (Ferments, USA), and $60 \mathrm{ng}$ of the template under the following conditions: $5 \mathrm{~min}$ at $94{ }^{\circ} \mathrm{C}$, followed by 
Table 1 Primer sequences for specific genes

\begin{tabular}{ll}
\hline Gene & Primer sequence \\
\hline SOD & Forward: 5'-ACGAAGGGAGGTGGATGCTG-3' \\
& Reverse: 5'-ACGGTGGAGGCGTTCTGCT-3' \\
NOS & Forward: 5'-TTGGAGCGAGTTGTGGATTG-3' \\
& Reverse: 5'-TGAGGGCTTGGCTGAGTGA-3' \\
GPX & Forward: 5'-GCCTGGATGGGGAGAAGATA-3' \\
& Reverse: 5'-GCAAGGGAAGCCGAGAACTA-3' \\
$\beta$-actin & Forward: 5'-GAGACCT TCAACACCCCAGC-3' \\
& Reverse: 5'- ATGTCACGCACGATTCCC -3'
\end{tabular}

$S O D$ superoxide dismutase, NOS nitric oxide synthase, GPX glutathione peroxidase

35 cycles of $60 \mathrm{~s}$ at $94{ }^{\circ} \mathrm{C}, 50 \mathrm{~s}$ at $56{ }^{\circ} \mathrm{C}$ or $67{ }^{\circ} \mathrm{C}$, and $50 \mathrm{~s}$ at $72{ }^{\circ} \mathrm{C}$ and $10 \mathrm{~min}$ at $72{ }^{\circ} \mathrm{C}$. PCR reactions were terminated before the reaction reached platform, and amplicons were examined using gel electrophoresis.

\section{Statistical analysis}

Statistical evaluation was performed using SPSS 18.0 package (SPSS Inc., Chicago, IL, USA). All data are expressed as mean \pm S.D. The t-test was used to compare differences between the two groups in the in vitro analysis. One-way analysis of variance was used

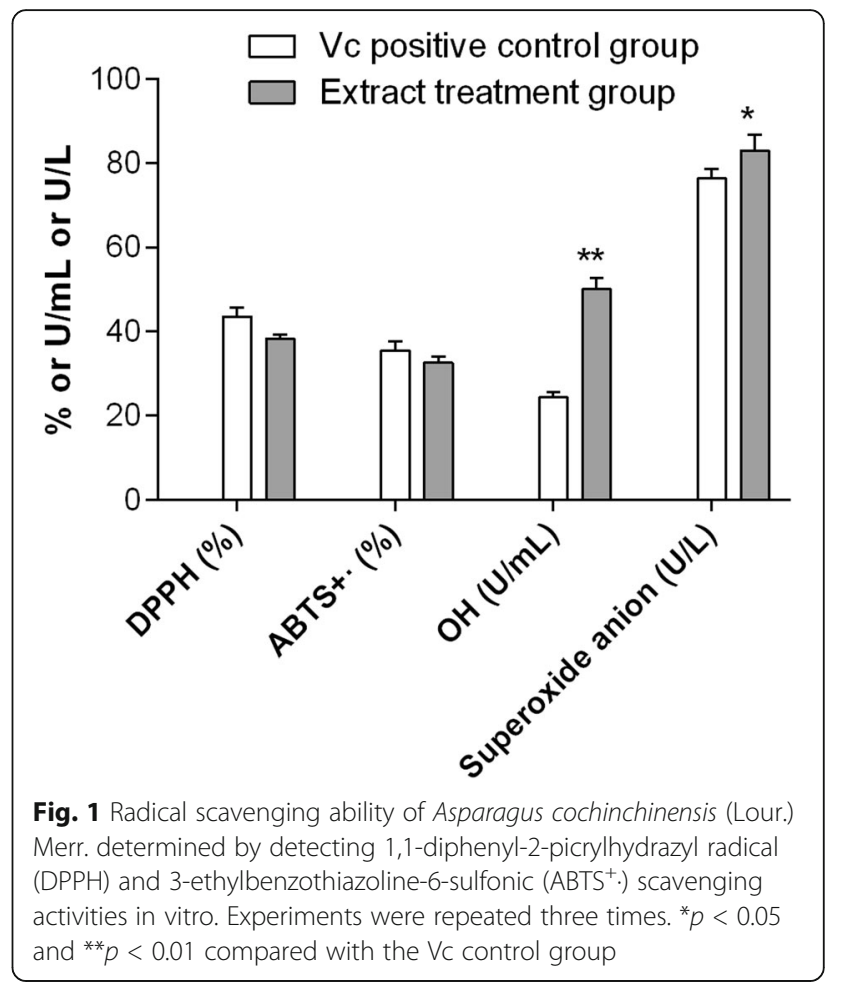

Table 2 Effects of Asparagus cochinchinensis (Lour.) Merr on the activities of NOS, CAT and SOD

\begin{tabular}{|c|c|c|c|c|}
\hline & Treatment & SOD/U mg ${ }^{-1}$ prot & $\mathrm{NOS} / \mathrm{U} \mathrm{mg}^{-1}$ prot & CAT/U $\mathrm{mg}^{-1}$ prot \\
\hline \multirow[t]{4}{*}{ Brain } & Negative control group & $98.31 \pm 4.44^{\mathrm{a}}$ & $1.48 \pm 0.04^{\mathrm{a}}$ & $32.34 \pm 0.98^{b}$ \\
\hline & Aging model group & $63.99 \pm 4.20^{b}$ & $1.35 \pm 0.06^{b}$ & $20.67 \pm 2.16^{c}$ \\
\hline & Vc positive control group & $100.36 \pm 5.01^{a}$ & $1.59 \pm 0.05^{a}$ & $48.11 \pm 2.17^{\mathrm{a}}$ \\
\hline & Extract treatment group & $95.58 \pm 4.05^{\mathrm{a}}$ & $1.61 \pm 0.06^{\mathrm{a}}$ & $46.85 \pm 1.81^{\mathrm{a}}$ \\
\hline \multirow[t]{4}{*}{ Liver } & Negative control group & $55.65 \pm 2.81^{b}$ & $0.84 \pm 0.13^{b}$ & $54.61 \pm 3.32^{\mathrm{a}}$ \\
\hline & Aging model group & $49.54 \pm 2.88^{C}$ & $0.74 \pm 0.12^{c}$ & $45.72 \pm 4.51^{b}$ \\
\hline & Vc positive control group & $59.75 \pm 3.89^{a}$ & $1.24 \pm 0.31^{a}$ & $56.18 \pm 4.38^{\mathrm{a}}$ \\
\hline & Extract treatment group & $60.98 \pm 4.09^{\mathrm{a}}$ & $1.12 \pm 0.29^{\mathrm{a}}$ & $55.16 \pm 5.09^{a}$ \\
\hline \multirow[t]{4}{*}{ Serum } & Negative control group & $86.42 \pm 9.29^{b}$ & $40.52 \pm 3.32^{b}$ & $0.31 \pm 0.08^{a}$ \\
\hline & Aging model group & $72.58 \pm 6.47^{c}$ & $33.76 \pm 4.51^{c}$ & $0.12 \pm 0.013^{b}$ \\
\hline & Vc positive control group & $96.97 \pm 7.87^{\mathrm{a}}$ & $47.55 \pm 3.69^{a}$ & $0.34 \pm 0.06^{\mathrm{a}}$ \\
\hline & Extract treatment group & $98.65 \pm 8.00^{\mathrm{a}}$ & $47.21 \pm 3.24^{a}$ & $0.35 \pm 0.057^{\mathrm{a}}$ \\
\hline \multirow[t]{4}{*}{ Heart } & Negative control group & $51.58 \pm 2.96^{\mathrm{a}}$ & $0.51 \pm 0.06^{\mathrm{a}}$ & $5.06 \pm 0.75^{a}$ \\
\hline & Aging model group & $33.96 \pm 2.19^{c}$ & $0.26 \pm 0.05^{b}$ & $1.53 \pm 0.38^{b}$ \\
\hline & Vc positive control group & $42.87 \pm 1.89^{b}$ & $0.54 \pm 0.07^{\mathrm{a}}$ & $5.01 \pm 0.54^{a}$ \\
\hline & Extract treatment group & $44.75 \pm 2.45^{b}$ & $0.48 \pm 0.09^{\mathrm{a}}$ & $4.91 \pm 0.45^{\mathrm{a}}$ \\
\hline \multirow[t]{4}{*}{ Kidney } & Negative control group & $56.24 \pm 4.57^{b}$ & $1.76 \pm 0.27^{\mathrm{a}}$ & $14.30 \pm 1.34^{b}$ \\
\hline & Aging model group & $50.87 \pm 5.09^{c}$ & $1.51 \pm 0.14^{b}$ & $5.24 \pm 1.06^{c}$ \\
\hline & Vc positive control group & $63.77 \pm 5.31^{a}$ & $1.68 \pm 0.15^{a}$ & $17.65 \pm 1.87^{\mathrm{a}}$ \\
\hline & Extract treatment group & $61.33 \pm 6.47^{\mathrm{a}}$ & $1.79 \pm 0.20^{\mathrm{a}}$ & $18.73 \pm 1.61^{a}$ \\
\hline
\end{tabular}

Note: Data were expressed as mean \pm SD; One-way analysis of variance (ANOVA) was used to analyze the difference among groups; Values with different letters showed significant difference 
for comparing differences among the four groups in the in vivo analysis. A value of $p<0.05$ was considered significant for all tests.

\section{Results}

\section{Radical scavenging ability in vitro}

Compared with the Vc positive control group, $0.7 \mathrm{~g} / \mathrm{mL}$ aqueous root extract of $A$. cochinchinensis had similar $\mathrm{DPPH}$-and $\mathrm{ABTS}^{+}$.scavenging activities, but significantly increased superoxide anion $(p<0.05)$ and $\mathrm{OH}$ scavenging activities $(p<0.01)$ (Fig. 1), which suggested strong radical scavenging ability of the aqueous root extract in vitro.

\section{Antioxidation ability in vivo}

As shown in Table 2, CAT, NOS, and SOD activities were clearly lower in the serum, kidney, heart, brain, and liver samples $(p<0.05)$ of the aging model group than in that of the negative control group. SOD, NOS, and CAT activities in the extract treatment group were elevated $(p<0.05)$ compared with those in the aging model group. No significant difference was observed in NOS, CAT, and SOD activities between the extract treatment group and Vc group. These results indicate that the aqueous root extract had similar activities for enzymes of the antioxidant system in comparison with Vc. Moreover, compared with the control group, decreased NO content and increased MDA content were observed in the aging model group $(p<0.05)$, whereas the extract of $A$. cochinchinensis significantly increased the NO content in aging mice and reduced their MDA content (Table 3). Meanwhile, NO and MDA contents were similar between extract treatment and Vc groups (Table 3).

\section{Effect of the aqueous root extract of $A$. cochinchinensis on} the microstructure of mouse viscera

HE results of tissues are shown in Fig. 2. In the control group, myocardial fiber cells were shuttle-shaped and arranged in parallel; had clear intercellular boundaries, close packing, clear visible band and intercalated disc; and distinct gradation in kidney, heart, brain, lung, and liver tissues. However, plump myocardial fiber cells, clear capillary vessels, and a widened interval were found in these tissues in the aging model group. After treatment with the aqueous root extract of $A$. cochinchinensis or Vc, a clear improvement in mouse viscera was observed. However, the aqueous root extract of $A$. cochinchinensis showed protective effects on the liver, brain, and kidney.

\section{Transcriptional gene expression levels related to antioxidation}

As shown in Fig. 3, compared with the control group, NOS, SOD, and GPX expression levels were significantly reduced in the aging group. However, compared with
Table 3 Effects of Asparagus cochinchinensis (Lour.) Merr on the $\mathrm{NO}$ and MDA contents

\begin{tabular}{llll}
\hline & Treatment & $\mathrm{NO} / \mu \mathrm{mol} \mathrm{L}^{-1}$ & $\mathrm{MDA} / \mathrm{U} \mathrm{mg^{-1 }}$ prot \\
\hline Brain & Negative control group & $12.50 \pm 1.06^{\mathrm{b}}$ & $1.43 \pm 0.089^{\mathrm{b}}$ \\
& Aging model group & $5.08 \pm 0.850^{\mathrm{c}}$ & $2.59 \pm 0.25^{\mathrm{a}}$ \\
& Vc positive control group & $26.36 \pm 1.89^{\mathrm{a}}$ & $0.89 \pm 0.034^{\mathrm{c}}$ \\
Liver & Extract treatment group & $24.34 \pm 1.83^{\mathrm{a}}$ & $1.05 \pm 0.028^{\mathrm{c}}$ \\
& Negative control group & $4.95 \pm 0.17^{\mathrm{b}}$ & $1.12 \pm 0.27^{\mathrm{b}}$ \\
& Aging model group & $1.91 \pm 0.16^{\mathrm{c}}$ & $1.55 \pm 0.14^{\mathrm{a}}$ \\
Vc positive control group & $5.57 \pm 0.36^{\mathrm{a}}$ & $0.98 \pm 0.11^{\mathrm{c}}$ \\
Serum & Extract treatment group & $5.64 \pm 0.31^{\mathrm{a}}$ & $1.10 \pm 0.20^{\mathrm{b}}$ \\
& Negative control group & $907.64 \pm 46.14^{\mathrm{b}}$ & $24.96 \pm 3.80^{\mathrm{b}}$ \\
& Aging model group & $503.26 \pm 27.08^{\mathrm{c}}$ & $29.64 \pm 4.46^{\mathrm{a}}$ \\
& Vc positive control group & $987.89 \pm 51.27^{\mathrm{a}}$ & $21.87 \pm 3.14^{\mathrm{c}}$ \\
Extract treatment group & $965.52 \pm 41.44^{\mathrm{a}}$ & $22.97 \pm 2.81^{\mathrm{c}}$ \\
Heart & Negative control group & $4.08 \pm 0.92^{\mathrm{a}}$ & $0.39 \pm 0.078^{\mathrm{b}}$ \\
& Aging model group & $1.10 \pm 0.24^{\mathrm{c}}$ & $2.53 \pm 0.35^{\mathrm{a}}$ \\
Vc positive control group & $3.77 \pm 0.44^{\mathrm{b}}$ & $0.36 \pm 0.08^{\mathrm{b}}$ \\
Kidney & Extract treatment group & $3.61 \pm 0.38^{\mathrm{b}}$ & $0.45 \pm 0.08^{\mathrm{b}}$ \\
Negative control group & $6.12 \pm 0.62^{\mathrm{b}}$ & $2.24 \pm 0.39^{\mathrm{b}}$ \\
Aging model group & $3.09 \pm 0.27^{\mathrm{c}}$ & $4.90 \pm 0.51^{\mathrm{a}}$ \\
Vc positive control group & $12.66 \pm 1.45^{\mathrm{a}}$ & $1.69 \pm 0.49^{\mathrm{c}}$ \\
Extract treatment group & $13.21 \pm 1.67^{\mathrm{a}}$ & $1.73 \pm 0.45^{\mathrm{c}}$ \\
\hline
\end{tabular}

Note: Data were expressed as mean $\pm \mathrm{SD}$; One-way analysis of variance (ANOVA) was used to analyze the difference among groups; Values with different letters showed significant difference

NO nitric oxide, MDA malondialdehyde

the aging model group, NOS, SOD, and GPX expression levels in the serum after treatment with root extract and Vc were elevated. NOS and GPX gene expression levels were increased in the extract treatment group compared with those in the negative control group. Moreover, NOS, SOD, and GPX gene expression levels in the liver of the negative control group was similar to those in the liver of the extract treatment group. In addition, NOS, SOD, and GPX gene expression levels in the kidney were similar among the control, $\mathrm{Vc}$, and extract treatment groups.

\section{Discussion}

The present study investigated the mechanism of action of the natural antioxidant $A$. cochinchinensis in the aging process. The results revealed that the aqueous root extract of $A$. cochinchinensis showed strong radical scavenging ability in vitro and could also increase $S O D$ and GPX expression levels and SOD and CAT activities in vivo. Moreover, the aqueous root extract of $A$. cochinchinensis reduced the MDA content, increased the $\mathrm{NO}$ content, and played important roles in pathological changes in the liver, kidney, and brain. 


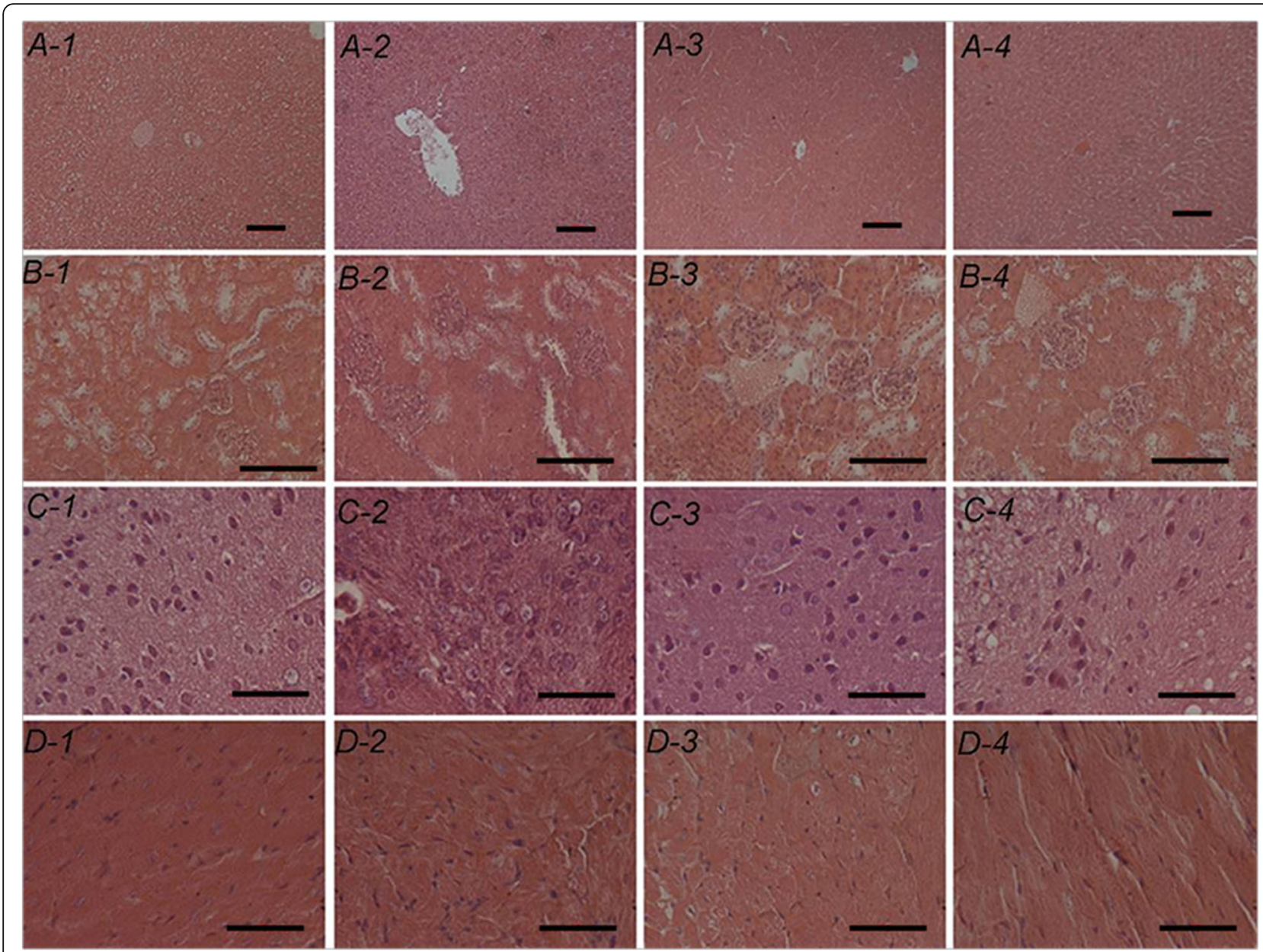

Fig. 2 Different tissues stained with hematoxylin and eosin obtained from D-galactose-induced senile mice. A, liver; B, kidney; C, brain; D, heart; 1, the control group; 2, the aging model group; 3, the Vc control group; and 4, the extract treatment group. Scale bars: 100 um (liver and kidney) or $50 \mu \mathrm{m}$ (brain and heart)

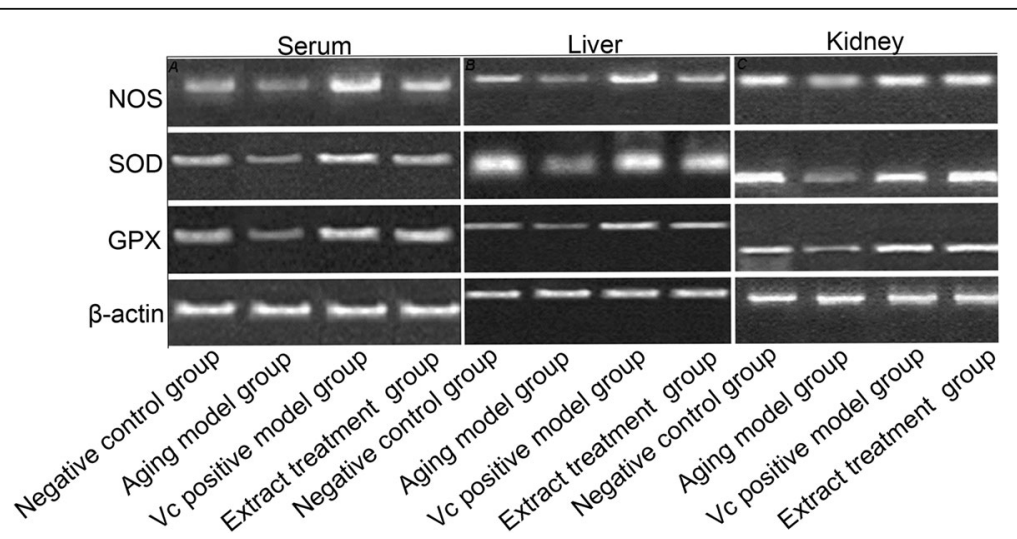

Fig. 3 Nitric oxide synthase (NOS), superoxide dismutase (SOD), and glutathione peroxidase (GPX) gene expression levels in the serum, liver, and kidney, as determined by semi-quantitative reverse-transcription polymerase chain reaction 
A previous study showed that radicals could cause all kinds of diseases related to oxidative damage, such as cancer, cardiovascular disease, immune system defects, and aging [19]. Natural substances have been considered to inhibit radical-caused damage [20] and radical production [21]. MDA, as a peroxide product of lipids, could reflect oxygen radical production [22]. SOD could reduce MDA production by inducing a disproportionation reaction of superoxide radicals [23]. CAT, as an antioxidant enzyme, was also reported to influence peroxide hydrogen production [24]. GPX was also reported to reduce oxidative stress [25]. This study found that the aqueous root extract of $A$. cochinchinensis showed radical scavenging ability in vitro and could significantly influence SOD, CAT, GPX, and MDA activities or contents in vivo, indicating that the radical scavenging ability of aqueous root extract might be mediated by antioxidant enzymes.

Moreover, we found that NOS gene expression and NO content were upregulated in aging mice after been treated with the aqueous root extract of $A$. cochinchinensis. $\mathrm{NO}$ is produced from L-arginine by NOS, and reduced NOS activity could result in aging [26]. Therefore, the aqueous root extract of $A$. cochinchinensis might promote antioxidant activity by enhancing NOS expression and NO content. Previous studies also indicated that $\mathrm{NO}$ was associated with a series of physiological processes and NO could enhance the antioxidant activity [27, 28]. In addition, the overexpressed NO might cause aging by inducing toxicity of superoxide anions $[29,30]$. Thus, we speculated that the aqueous root extract of $A$. cochinchinensis might influence $\mathrm{NO}$ production and then delay the aging process by destroying homeostasis.

\section{Conclusions}

In conclusion, the antioxidant ability of the aqueous root extract of $A$. cochinchinensis was shown to occur through enhancement of antioxidant enzyme expression levels, increase in NOS, CAT, and SOD activities and the NO content, and reduction in the MDA content. However, chemical analysis of the extract is still required for identifying its active ingredient.

\section{Abbreviations}

$\mathrm{ABTS}^{+}$: 3-ethylbenzothiazoline-6-sulfonic; CAT: Catalase; DPPH: 1,1-diphenyl-2picrylhydrazyl radical; GPX: Glutathione peroxidase; KM: KunMing; MDA: Malondialdehyde; NO: Nitric oxide; NOS: Nitric oxide synthase; $\mathrm{OH}$ : Hydroxyl radical; SOD: Superoxide dismutase; Vc: Vitamin C

\section{Acknowledgements}

We thank Horticulture of the advantage and characteristics priority discipline of the 12th five-year plan of Hunan Province. We wish to express our warm thanks to Fenghe (Shanghai) Information Technology Co., Ltd. Their ideas and help gave valuable added dimension to our research.

\section{Funding}

This study was supported by Science and Technology Project of Hunan Province (No. 2012FJ4292; No. 2011NK3046), Priority Development Discipline of Hunan Province (No. 2011042), and Ecology of First-class Subject of Zhejiang province, Public Welfare Technology Application Research Project of Lishui (2017).

Availability of data and materials

All data generated or analyzed during this study are included in this published article.

\section{Authors' contributions}

LO participated in designing this study. YC performed the statistical analysis. $\mathrm{LL}$ performed the study and collected important background information. YLX and XYY conceived this study, designed it, and helped in drafting the manuscript. All authors read and approved the final manuscript.

\section{Ethics approval and consent to participate}

Approval was obtained from the animal ethics committee of the Animal Laboratory Center of Xiangya Medical School of Central South University prior to using the animals for the experiments.

Consent for publication

Not applicable.

Competing interests

The authors declare that they have no competing interests.

\section{Publisher's Note}

Springer Nature remains neutral with regard to jurisdictional claims in published maps and institutional affiliations.

\section{Author details}

${ }^{1}$ College of Ecology, Lishui University, Lishui, Zhejiang 323000, China. ${ }^{2}$ College of Horticulture and Landscape, Hunan Agriculture University, Changsha, Hunan 410128, China. ${ }^{3}$ Vegetable Research Insitute, Agricultural Sciences Academy of Hunan Provincial, Changsha, Hunan 410125, China.

${ }^{4}$ Hunan Institute of Science and Technology, Yueyang, Hunan 414006, China.

Received: 8 January 2017 Accepted: 14 September 2017

Published online: 25 September 2017

\section{References}

1. Dillin A, Gottschling DE, Nyström T. The good and the bad of being connected: the integrons of aging. Curr Opin Cell Biol. 2014;26:107-12.

2. Harman D. Aging: a theory based on free radical and radiation chemistry. J Gerontol. 1955;11:298-300.

3. Suh H-J, Chung M-S, Cho Y-H, Kim J-W, Kim D-H, Han K-W, Kim C-J. Estimated daily intakes of butylated hydroxyanisole (BHA), butylated hydroxytoluene $(\mathrm{BHT})$ and tert-butyl hydroquinone (TBHQ) antioxidants in Korea. Food Addit Contam. 2005;22:1176-88.

4. Asaduzzaman Khan M, Tania M, D-z Z, H-c C. Antioxidant enzymes and cancer. Chin J Cancer Res. 2010;22:87-92.

5. Fisch KM, Böhm V, Wright AD, König GM. Antioxidative Meroterpenoids from the Brown alga Cystoseira crinita. J Nat Prod. 2003;66:968-75.

6. Saenz AT, Elisia I, Innis SM, Friel JK, Kitts DD. Use of ORAC to assess antioxidant capacity of human milk. J Food Compos Anal. 2009;22:694-8.

7. Duan S, Tang S, Qin N, Duan H. Chemical constituents of Phymatopteris hastate and their antioxidant activity. China journal of Chinese materia medica. 2012;37:1402-7.

8. Zheng H, Zhao J, Liu Y, Zheng Y, Wu J, Hong Z. Effect of total alkaloids of Rubus alceaefolius on oxidative stress in rats with non-alcoholic fatty liver disease. China journal of Chinese materia medica. 2011;36:2383-7.

9. Luo J, Li C, Li L, Huang N, Long Q. Inhibitory effects of ALWB and ACM on mice bearing tumor. Journal of Guiyang Medical College. 2000;25:15-6.

10. Le Son $H$, Anh NP. Phytochemical composition, in vitro antioxidant and anticancer activities of quercetin from methanol extract of Asparagus Cochinchinensis (Lour.) Merr. Tuber. Journal of Medicinal Plants Research. 2013;7:3360-6. 
11. FANG F, ZHANG H, Y-p ZHAO, W-b LI, YANG. L, LI D-y. In vitro antimicrobial test of Asparagus Cochinchinensis (Lour) Merr [J]. Hubei agricultural. Sciences. 2012;5:024.

12. Lee $\mathrm{D}$, Choo B, Yoon T, Cheon M, Lee H, Lee A, Kim H. Anti-inflammatory effects of Asparagus Cochinchinensis extract in acute and chronic cutaneous inflammation. J Ethnopharmacol. 2009;121:28-34.

13. Jalsrai A, Numakawa T, Kunugi H, Dieterich D, Becker A. The neuroprotective effects and possible mechanism of action of a methanol extract from Asparagus Cochinchinensis: in vitro and in vivo studies. Neuroscience. 2016;322:452-63.

14. Lei L, Ou L, Yu X. The antioxidant effect of Asparagus cochinchinensis (Lour.) Merr. shoot in d-galactose induced mice aging model and in vitro. Journal of the Chinese Medical Association. 2016;79:205-11.

15. Cui X, Zuo P, Zhang Q, Li X, Hu Y, Long J, Packer L, Liu J. Chronic systemic $D$-galactose exposure induces memory loss, neurodegeneration, and oxidative damage in mice: protective effects of R-a-lipoic acid. J Neurosci Res. 2006:83:1584-90.

16. Zhang P, Qu F, Bai J, Ou Q, Bai S. Effects of alcohol extract of asparagus cochinchinensis (Lour.) Merr on antioxidation of D-galatose-induced aging mice. Chinese Journal of Gerontology. 2000;1:1.

17. Committee CP. Chinese pharmacopoeia. Beijing: China Medica Science Press; 2010.

18. Salehpour F, Ahmadian N, Rasta S, Farhoudi M, Karimi P, Sadigh-Eteghad S. Transcranial low-level laser therapy improves brain mitochondrial function and cognitive impairment in D-galactose-induced aging mice. Neurobiol Aging. 2017:58:140-50.

19. Halliwell B. Free radicals, antioxidants, and human disease: curiosity, cause, or consequence? Lancet. 1994;344:721-4.

20. Alvarez-Suarez JM, Dekanski D, Ristic S, Radonjic NV, Petronijevic ND, Giampieri F, Astolfi P, González-Paramás AM, Santos-Buelga C, Tulipani S. Strawberry polyphenols attenuate ethanol-induced gastric lesions in rats by activation of antioxidant enzymes and attenuation of MDA increase. PLoS One. 2011;6:e25878.

21. Sun J, Bi J. Chemical composition and antioxidant activities of Broussonetia Papyrifera fruits. PLoS One. 2012;7:e32021.

22. Ambrosio G, Flaherty JT, Duilio C, Tritto I, Santoro G, Elia P, Condorelli M, Chiariello M. Oxygen radicals generated at reflow induce peroxidation of membrane lipids in reperfused hearts. J Clin Investig. 1991;87:2056-66.

23. Cadet IL, Ladenheim B, Baum I, Carlson E, Epstein C. CuZn-superoxide dismutase (CuZnSOD) transgenic mice show resistance to the lethal effects of methylenedioxyamphetamine (MDA) and of methylenedioxymethamphetamine (MDMA). Brain Res. 1994;655:259-62.

24. Melov S, Ravenscroft J, Malik S, Gill MS, Walker DW, Clayton PE, Wallace DC, Malfroy B, Doctrow SR, Lithgow GJ. Extension of life-span with superoxide dismutase/catalase mimetics. Science. 2000;289:1567-9.

25. Reiter RJ, Tan D-X, Osuna C, Gitto E. Actions of melatonin in the reduction of oxidative stress. J Biomed Sci. 2000;7:444-58.

26. Mollace V, Rodino P, Massoud R, Rotiroti D, Nistico G. Age-dependent changes of NO synthase activity in the rat brain. Biochem Biophys Res Commun. 1995:215:822-7.

27. Kibbe M, Billiar T, Tzeng E. Inducible nitric oxide synthase and vascular injury. Cardiovasc Res. 1999;43:650-7.

28. Dahiya K, Dhankhar R, Madaan H, Singh V, Arora K. Nitric oxide and antioxidant status in head and neck carcinoma before and after radiotherapy. Annals of Clinical \& Laboratory Science. 2012;42:94-7.

29. Jesko H, Chalimoniuk M, Strosznajder JB. Activation of constitutive nitric oxide synthase (s) and absence of inducible isoform in aged rat brain. Neurochem Int. 2003;42:315-22.

30. Law A, O'donnell J, Gauthier S, Quirion R. Neuronal and inducible nitric oxide synthase expressions and activities in the hippocampi and cortices of young adult, aged cognitively unimpaired, and impaired long-Evans rats. Neuroscience. 2002;112:267-75.

\section{Submit your next manuscript to BioMed Central and we will help you at every step:}

- We accept pre-submission inquiries

- Our selector tool helps you to find the most relevant journal

- We provide round the clock customer support

- Convenient online submission

- Thorough peer review

- Inclusion in PubMed and all major indexing services

- Maximum visibility for your research

Submit your manuscript at www.biomedcentral.com/submit
Biomed Central 